\title{
Evaluation of multi-mode CryoSat-2 altimetry data over the Po River against in situ data and a hydrodynamic model
}

Schneider, Raphael; Tarpanelli, Angelica; Nielsen, Karina; Madsen, Henrik; Bauer-Gottwein, Peter

Published in:

Advances in Water Resources

Link to article, DOI:

10.1016/j.advwatres.2017.11.027

Publication date:

2018

Document Version

Peer reviewed version

Link back to DTU Orbit

Citation (APA):

Schneider, R., Tarpanelli, A., Nielsen, K., Madsen, H., \& Bauer-Gottwein, P. (2018). Evaluation of multi-mode CryoSat-2 altimetry data over the Po River against in situ data and a hydrodynamic model. Advances in Water Resources, 112, 17-26. https://doi.org/10.1016/j.advwatres.2017.11.027

\section{General rights}

Copyright and moral rights for the publications made accessible in the public portal are retained by the authors and/or other copyright owners and it is a condition of accessing publications that users recognise and abide by the legal requirements associated with these rights.

- Users may download and print one copy of any publication from the public portal for the purpose of private study or research.

- You may not further distribute the material or use it for any profit-making activity or commercial gain

- You may freely distribute the URL identifying the publication in the public portal 


\section{Accepted Manuscript}

Evaluation of multi-mode CryoSat-2 altimetry data over the Po River against in situ data and a hydrodynamic model

Raphael Schneider, Angelica Tarpanelli, Karina Nielsen , Henrik Madsen, Peter Bauer-Gottwein

PII: S0309-1708(17)30779-0

DOI: 10.1016/j.advwatres.2017.11.027

Reference: $\quad$ ADWR 3032

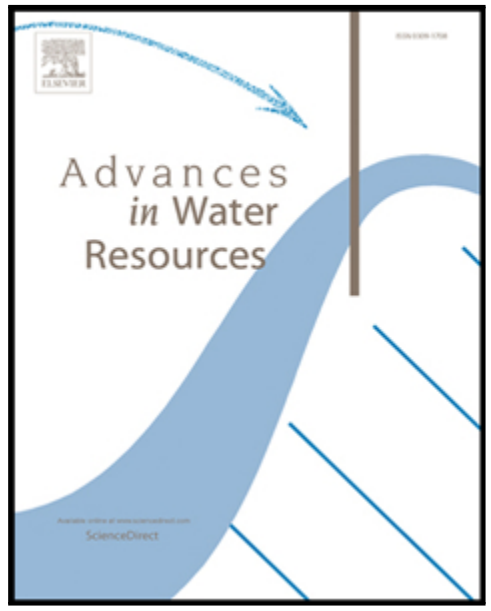

To appear in:

Advances in Water Resources

Received date:

3 August 2017

Revised date:

20 November 2017

Accepted date:

29 November 2017

Please cite this article as: Raphael Schneider, Angelica Tarpanelli, Karina Nielsen, Henrik Madsen, Peter Bauer-Gottwein, Evaluation of multi-mode CryoSat-2 altimetry data over the Po River against in situ data and a hydrodynamic model, Advances in Water Resources (2017), doi: 10.1016/j.advwatres.2017.11.027

This is a PDF file of an unedited manuscript that has been accepted for publication. As a service to our customers we are providing this early version of the manuscript. The manuscript will undergo copyediting, typesetting, and review of the resulting proof before it is published in its final form. Please note that during the production process errors may be discovered which could affect the content, and all legal disclaimers that apply to the journal pertain. 


\section{Highlights}

- First extensive validation of CryoSat-2 altimetry over rivers: $0.38 \mathrm{~m}$ average error

- Use of CryoSat-2 in channel roughness calibration of hydrodynamic model of Po River

- Dense sampling of CryoSat-2 along rivers can define variable Manning's roughness

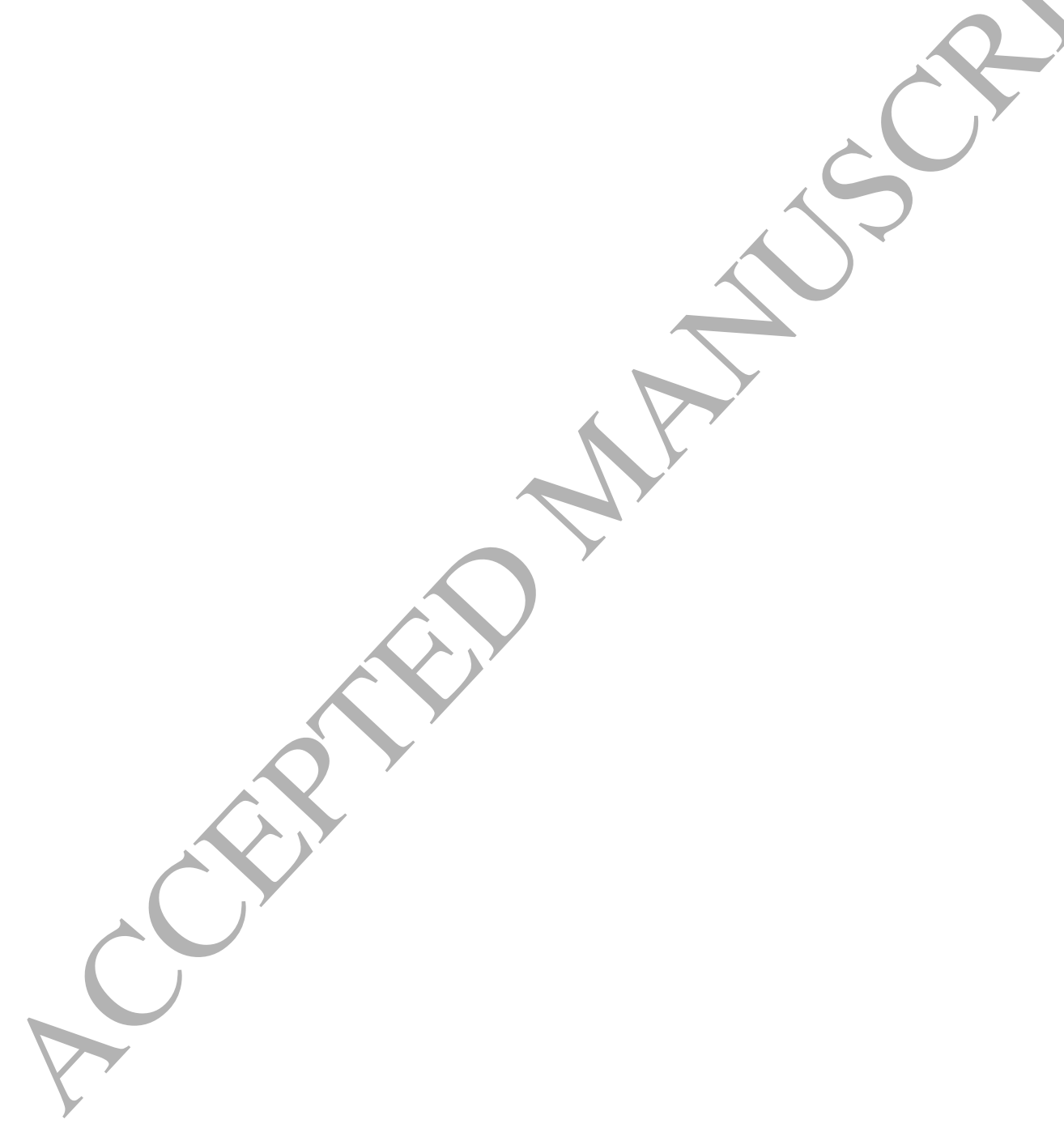




\section{Evaluation of multi-mode CryoSat-2 altimetry data over the Po River against in situ data and a hydrodynamic model}

Raphael Schneider*a, Angelica Tarpanelli ${ }^{\mathrm{b}}$, Karina Nielsen ${ }^{\mathrm{c}}$, Henrik Madsen $^{\mathrm{d}}$, Peter Bauer-Gottwein ${ }^{\mathrm{a}}$

a) Technical University of Denmark, Department of Environmental Engineering, Bygningstorvet, building 115, 2800 Kgs. Lyngby, Denmark

b) Research Institute for Geo-Hydrological Protection, National Research Council, Via della Madonna Alta 126, Perugia 06128, Italy

${ }^{c}$ National Space Institute, Technical University of Denmark, Elektrovej, building 328, 2800 Kgs. Lyngby, Denmark

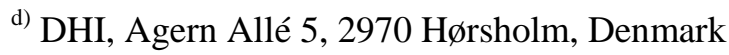

*Corresponding author: rasch@env.dtu.dk

\section{Abstract}

Coverage of in situ observations to monitor surface waters is insufficient on the global scale, and decreasing across the globe. Satellite altimetry has become an increasingly important monitoring technology for continental surface waters. The ESA CryoSat-2 altimetry mission, launched in 2010, has two novel features. (i) The radar altimeter instrument on board of CryoSat- 2 is operated in three modes; two of them reduce the altimeter footprint by using Delay-Doppler processing. (ii) CryoSat-2 is placed on a distinct orbit with a repeat cycle of 369 days, leading to a driftìng ground track pattern. The drifting ground track pattern challenges many common methods of processing satellite altimetry data over rivers. This study evaluates the observation error of CryoSat2 water level observations over the Po River, Italy, against in situ observations. The average RMSE between CryoSat- 2 and in situ observations was found to be 0.38 meters. CryoSat- 2 was also shown to be useful for channel roughness calibration in a hydrodynamic model of the Po River. The small across-track distance of CryoSat-2 means that observations are distributed almost continuously along the river. This allowed resolving channel roughness with higher spatial resolution than possible with in situ or virtual station altimetry data. Despite the Po River being extensively monitored, CryoSat-2 still provides added value thanks to its unique spatio-temporal sampling pattern. 
Keywords: CryoSat-2; rivers; satellite altimetry; river channel roughness; calibration; validation

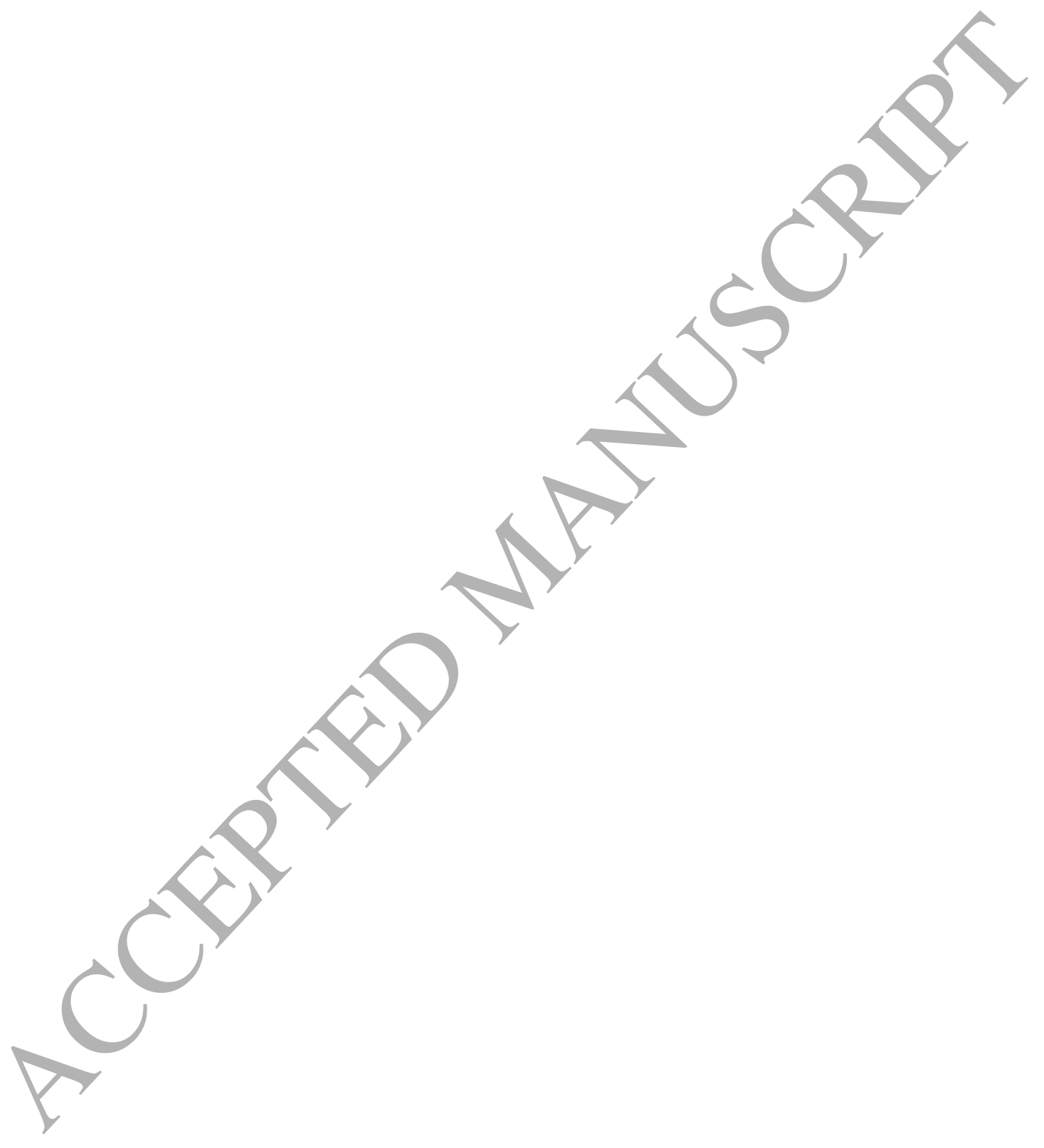




\section{Introduction and background}

Satellite altimetry, initially developed to monitor ocean water levels, also observes water levels of rivers and lakes. It plays an important role in monitoring changes in continental water levels, a crucial parameter to determine surface storage changes, estimating river discharge, deriving hydraulic and hydrologic parameters of poorly gauged river basins, and monitoring climate change impacts on surface waters (Alsdorf et al., 2007). Such remote sensing observations of water level are needed to complement or replace in situ observations, as their coverage on the global scale is insufficient to solve current water resources management challenges, and their availability is decreasing across the globe (Calmant and Seyler, 2006; World Water Assessment Programme, 2009). Increased availability of satellite data thanks to a continuous addition of new altimetry missions, and new methods to combine the altimetry data with hydrologic models have resulted in increased use and significance of the satellite radar altimetry datastream (Berry and Benveniste, 2010; Calmant et al., 2009). These missions have global coverage and deliver point observations along their ground tracks. However, factors such as rugged terrain or the size of the water bodies limit data availability or increase observation error. Currently, a river width of around $200 \mathrm{~m}$ has to be considered the minimum to obtain water level observation from satellite altimeters (Biancamaria et al., 2017; Maillard et al., 2015). Common observation errors are in the range of a few centimeters over lakes and a few decimeters over rivers (O'Loughlin et al., 2016; Villadsen et al., 2016).

The ESA satellite altimetry mission CryoSat-2 (European Space Agency and Mullard Space Science Laboratory, 2012) has a distinctive long-repeat ground track pattern. Its primary target is to observe sea ice and continental ice sheets. When used for monitoring of inland water bodies, especially rivers, the particular orbit configuration challenges common ways of processing and using satellite altimetry data: previous satellite altimeters have been on orbits with repeat cycles from 10 to 35 days. This allows to derive time series of water levels at locations where the satellite ground track interseets with the river, the so called virtual stations, with a temporal resolution equal to the orbit repeat period (Calmant et al., 2016). One example virtual station and its time series of observed water levels over the Po River are displayed in Figure 1. The orbit repeat period also determines the across-track distance, which conventionally is $80 \mathrm{~km}$ to $300 \mathrm{~km}$ at the equator. See Jiang et al. (2017) or Sehwatke et at. (2015) Calmant et al. (2016) for an overview of past and current satellite altimetry missions. The latter also provides an introduction into technical details of radar satellite altimetry over inland waters.

CryoSat-2, however, has an orbit with a full repeat cycle of 369 days, resulting in a so-called drifting ground track. This has two major consequences for the spatio-temporal sampling pattern: (i) time series of water levels at the same point have insufficient temporal resolution, but (ii) CryoSat-2 offers a very dense spatial sampling pattern with an across-track distance of only $7.5 \mathrm{~km}$ at the equator (Wingham et al., 2006). Because of (i) it is not straightforward to construct time series and remove outliers from CryoSat-2 data. As a consequence of (ii), 
continuous river masks are needed to extract relevant observations over water surfaces. For these reasons, application of CryoSat-2 altimetry over rivers is still limited (Jiang et al., 2017) In addition, no data from CryoSat-2 are yet included in inland altimetry databases such as DAHITI (http://dahiti.dgfi.tum.de/en/), HydroWeb (http://www.legos.obs-mip.fr/en/soa/hydrologie/hydroweb/) and HydroSat (http://hydrosat.gis.unistuttgart.de/php/index.php). Only CryoSat-2 data over lakes is readily available, for example provided by AltWater (http://altwater.dtu.space/). However, (ii) also can be seen as one of the main advantages of CryoSat-2, as it provides data with higher spatial resolution than conventional missions on short repeat orbits.

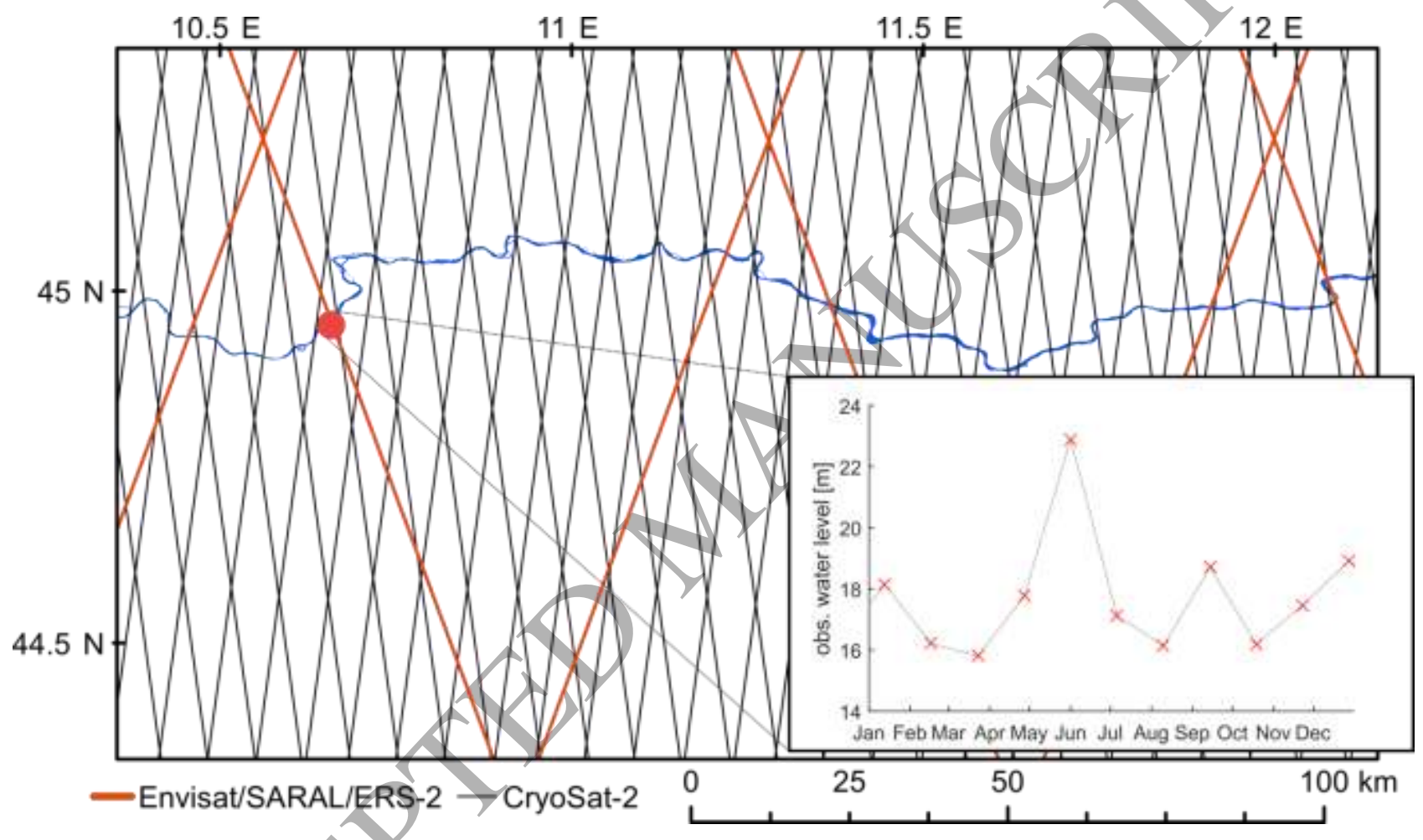

Figure 1: Comparison of ground tracks over the Po River. Envisat, SARAL, and ERS-2 have identical ground tracks with an equatorial track spacing of $\mathbf{8 0 ~ k m}$ and a repeat cycle of $\mathbf{3 5}$ days; they are displayed as an example for short repeat missions. An example virtual station is marked as a dot; with the respective time series of observed water levels in 2008 (data from DAHITI; Schwatke et al. (2015)). Due to its orbit configuration, no virtual station time series can be extracted from CryoSat-2.

Besides the special orbit configuration, CryoSat-2 also carries a new type of radar altimeter, named Synthetic Aperture Interferometric Radar Altimeter (SIRAL) (Wingham et al., 2006). It is a Ku-band radar and is operated in three distinct modes: in low resolution mode (LRM) it operates like a conventional radar altimeter (e.g. RA-2 on Envisat) with a circular footprint with a diameter of $1.65 \mathrm{~km}$ on a smooth surface (European Space Agency and Mullard Space Science Laboratory, 2012). In Synthetic Aperture Radar (SAR) mode, the along-track footprint is reduced to $300 \mathrm{~m}$ via Delay-Doppler processing. Finally, the Synthetic Aperture Radar 
Interferometry (SARIn) mode applies SAR mode processing alongside the use of a second antenna to determine the across-track angle of the main radar return. A geographical mode mask (available at https://earth.esa.int/web/guest/-/geographical-mode-mask-7107) determines where on the globe which mode is used. SARIn mode is mainly used over mountainous regions and margins of ice sheets, SAR mode in many coastal regions, and LRM mode everywhere else.

CryoSat-2 has been validated over lakes (Göttl et al., 2016; Nielsen et al., 2015), but so far only some attempts have been reported to evaluate its accuracy over rivers. For example, Villadsen et al. (2015) compared CryoSat-2 observations over the Ganges and Brahmaputra Rivers against virtual station altimetry data from Envisat. Tourian et al. (2016) used a quantile-based approach to transfer distributed satellite altimetry observations to specified stations (in situ stations). Their method, however, is best suited for virtual station data. Villadsen et al. (2016) evaluated CryoSat-2 accuracy over Lake Vänern, Lake Okeechobee, and over a single in situ station in the Amazon River with daily water level data. Also Bercher et al. (2013) evaluated CryoSat-2 observations over a tributary of the Amazon River against data from a single in situ station. Over these river stations, CryoSat-2 was found to perform similarly to previous missions, with errors in the range of a few decimeters.

CryoSat-2 altimetry is potentially very useful: due to its small across-track distance, practically continuous river water level profiles can be derived. This can normally not be áchieved using any other altimetry missions and was exploited to calibrate cross section shapes in a model of the ungauged Brahmaputra River (Schneider et al., 2017). Before that, O’Loughlin et al. (2013) performed a hydraulic characterization of the ungauged Congo River, using water level data from the lidar altimeter ICESat (Schutz et al., 2005). ICESat has an orbit configuration in between all the short repeat missions and the drifting ground track CryoSat-2; hence, it does not provide water level profiles as dense as from CryoSat-2. The usefulness of remotely sensed water level profiles is also acknowledged by Garambois et al. (2016): for a river flowing more or less along the satellite ground track, also repeat orbit missions can observe river water level profiles. They exploit this effect over a tributary of the Amazon River, using Envisat data, and derive different hydraulic information of the river.

In this context, the present study aims to investigate the potential of the Cryosat-2 over rivers, and, specifically, the capabilities of the three operational modes of the SIRAL instrument. For a comprehensive evaluation of the performance, the Po River in Italy is used as a case study because:

i. $\quad$ it is covered by all three modes of CryoSat-2;

ii. it is a relatively narrow river, allowing transferability of the results to many rivers globally; 
iii. it has a dense network of in situ gauging stations with high temporal resolution and reliable height reference, allowing evaluation of absolute water levels (and not just water level amplitudes or similar as done in previous studies).

Besides this, we used a hydrodynamic model currently employed in the flood forecasting system by the Interregional Agency for the Po River (AIPo), based on surveyed cross sections. The unique drifting ground track pattern of CryoSat-2 is exploited to calibrate channel roughness in the model, varying spatially along the river.

\section{Data and methods}

\subsection{Study region - the Po River}

The Po River (Figure 2) is situated in Northern Italy. It drains a basin of $71000 \mathrm{~km}^{2}$ and its main reach has a length of about $650 \mathrm{~km}$. Significant parts of the Po basin are mountainous; situated in the Southern Alps and Northern Apennines. The main reach, however, is mainly situated in the flat Padana Plain which the Po River crosses from west to east. It is predominantly a single-channel river with river widths around $200 \mathrm{~m}$ to $300 \mathrm{~m}$, reaching a maximum of $500 \mathrm{~m}$. The Po River has an average discharge of around $1500 \mathrm{~m}^{3} \mathrm{~s}^{-1}$ at its outlet and it exhibits two annual high-flow periods, the first in spring dominated by snowmelt and the second in fall mainly due to higher rainfall during that season (Montanari, 2012).

\subsection{CryoSat-2 data}

The CryoSat-2 data used in this study is level 2 data. It is based on $20 \mathrm{~Hz}$ level $1 \mathrm{~b}$ baseline $\mathrm{C}$ data provided by ESA, and retracked with an empirical Narrow Primary Peak Retracker (NPPR) (Villadsen et al., 2016).

Altimetry data from the beginning of the CryoSat-2 mission in July 2010 until November 2016 was used. All water levels were converted to the local ITALGEO 2005 geoid (Barzaghi et al., 2007). Along different parts of the Po River, CryoSat-2 operated in all of its three operation modes - initially SARIn mode in areas closest to the Alps, SAR mode in regions close to the coast of the Adriatic Sea, and LRM in all other areas. The mode mask over the study/region, however, has been changed considerably during the mission duration. In July 2014 (mode mask version 3.5) all areas previously covered in LRM mode were converted to SAR mode. Later, in December 2015 (mode mask version 3.7), the SARIn mask was extended to cover most parts of the Po River except for the regions closest to the Adriatic Sea. An overview of the data is illustrated in Figure 2. 


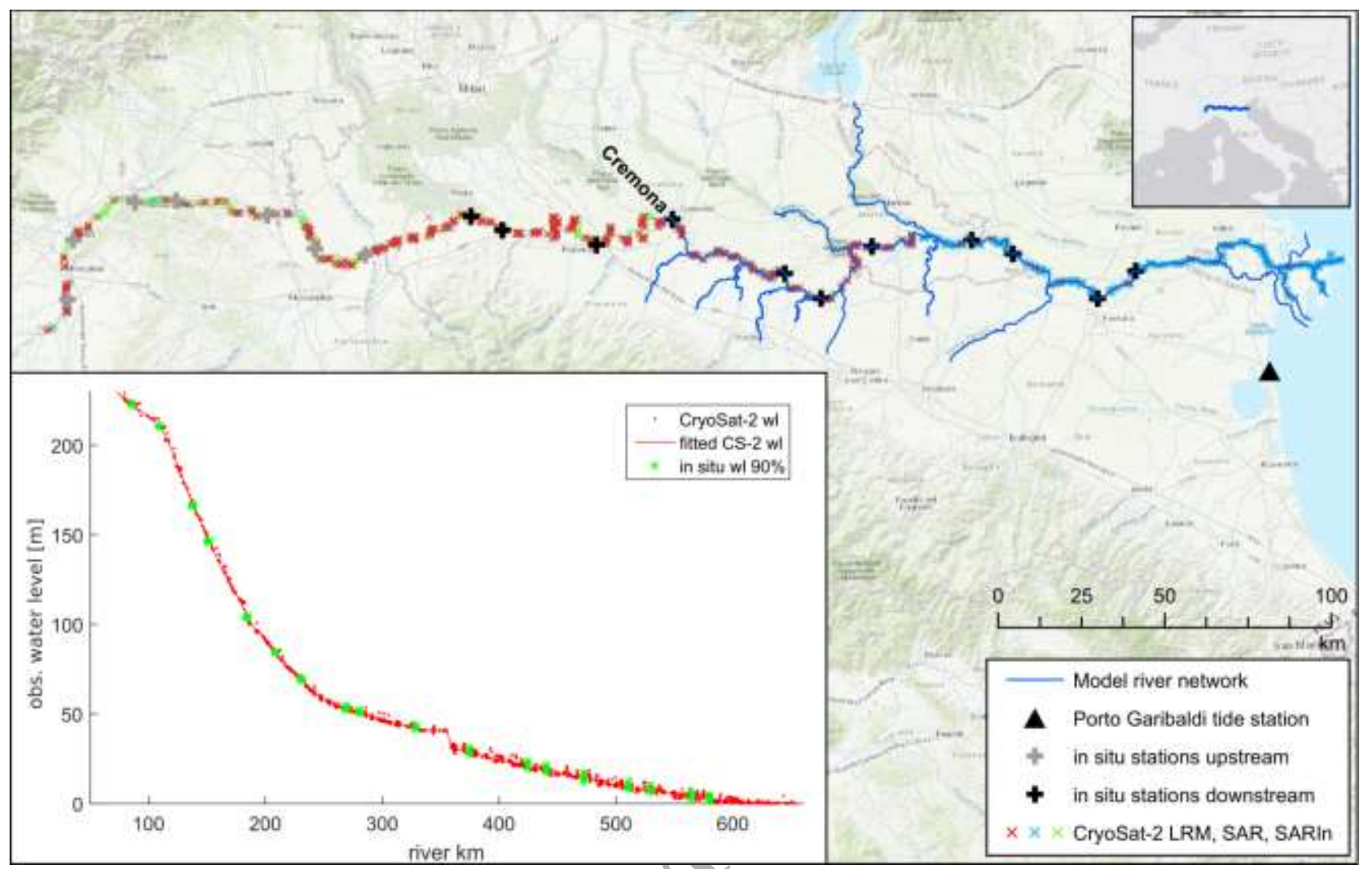

Figure 2: Basemap of the Po River, showing the filtered CryoSat-2 observations, in situ stations and the model river network. The inlet shows the water levels of all CryoSat-2 observations along the river line as well as the mean and $90 \%$ quantiles of the in situ observations. The river flows from east to west; river chainage increases in downstream direction.

CryoSat-2 Level 2 water heights were extracted using a binary river mask derived from Landsat- 8 Normalized Difference Vegetation Index (NDVI) imagery. Because seasonal and inter-annual water extent variations are small, the use of a static water mask is appropriate for the Po River. All areas with a NDVI value of 0 or below were considered water surfaces. Optical imagery, and the derived NDVI or Normalized Difference Water Index (NDWI) are commonly used to derive high resolution river masks (Birkinshaw et al., 2014; Michailovsky et al., 2012; Neal et al., 2012; Q'Loughlin et al., 2013). In order to obtain as many water level observations as possible, the river mask was extended using GIS buffering routines. Eventually, we settled on a buffering distance of $90 \mathrm{~m}$ because the buffering almost doubled the number of data points without an appreciable increase in the noise level. This behavior can be explained by the altimeter footprint configuration in the along-track direction. The footprint illuminates the river even though the nadir position of the satellite is outside the river. Hence, a water return can be captured before and after the satellite crosses the river. This effect is referred to as the hooking effect (Frappart et al., 2006), which is most pronounced for conventional LRM where the footprint can have a diameter of several $\mathrm{km}$. For the SAR and SARIn modes the effect is still present, though much smaller due to the 
reduced footprint size of approximately $300 \mathrm{~m}$ in the along-track direction. As we only used measurements from the very vicinity of the actual water surface, the effect of the parabolic distortions of observed water levels caused by the hooking effect (Santos da Silva et al., 2010) is negligible.

It is common that the observation error of satellite altimeters contains a systematic part (Calmant et al., 2016). These biases are especially important when working with multi-mission datasets (e.g. Jarihani et a1., 2013; Schwatke et al., 2015). The systematic bias in the CryoSat-2 retracked heights was estimated based on a comparison of CryoSat-2 data with tide gauge data from Porto Garibaldi station available from the Permanent Service for Mean Sea Level (PSMSL) (http://www.psmsl.org/data/obtaining/stations/2144.php\#docu), similar to, for example, Tourian et al. (2016). The location of the station is indicated in Figure 2. Over this region, CryoSat2 has been operating in SAR mode throughout its mission life time. The in situ data provides mean monthly water levels at the station. These mean monthly water levels were compared with all available CryoSat-2 observations in the vicinity, and a bias determined from this. The bias was found to be $\sim 25 \mathrm{~cm}$ (CryoSat-2 below tide gauge). This bias was assumed to be constant over time, for the entire Po River region, and for all observation modes of CryoSat-2. Hence, all CryoSat-2 observations were corrected with this bias before further processing.

A local regression curve was fitted to the available CryoSat-2 data along the river. The fitted curve was assumed to represent the mean of observed water levels. All observations deviating more than 5 meters from this mean water level were considered as outliers. The 5 meters threshold, effectively allowing an amplitude of 10 meters, was chosen based on the observed water level amplitudes at the in situ stations, which are all below 10 meters.

2302 single CryoSat-2 observations over the Po River were extracted using the river mask described above. The outlier filtering removed roughly $4 \%$ of the observations, with 2217 remaining: 735 in LRM mode, 1062 in SAR mode and 420 in SARIn mode. These 2217 single observations originate from 803 orbits of CryoSat- 2. This means that, on average, per transect across the Po River there are only 2.8 single observations available. Because of the low number of observations per transect and the drifting ground track pattern, alternative ways of outlier filtering, such as commonly used time series analysis or analysis of single transects (as done for example in the DAHITI and HydroWeb databases, see Santos da Silva et al., 2010; Schwatke et al., 2015), cannot be applied here.

\subsection{Evaluation of CryoSat-2 data against in situ data}

AIPo provides access to water level data from a series of stations along the Po River and its tributaries (http://www.agenziainterregionalepo.it/dati-idrologici.html). Table 1 lists the 18 stations along the Po River that 
were used for this study. Their locations are indicated in Figure 2. All elevations are given in the same reference system as the CryoSat-2 data, the ITALGEO 2005 geoid.

Table 1: Overview over in situ stations along the Po River. River chainage refers to the stations chainage in the model (section 2.4). River width is given as approximate values. The 6 most upstream stations (below the dashed line; indicated in grey in Figure 2) are excluded from most of the analysis.

\begin{tabular}{|c|c|c|c|c|}
\hline Station name & river chainage [m] & $\begin{array}{c}\text { mean water level } \\
{[\mathrm{m}]}\end{array}$ & $\begin{array}{c}\text { missing values in } \\
{[\%]}\end{array}$ & river width [m] \\
\hline Polesella SIAP & 580161 & 2.84 & 1.0 & 300 \\
\hline Pontelagoscuro SIAP & 564229 & 4.05 & 0.6 & 300 \\
\hline Sermide & 529206 & 8.01 & 5.8 & 300 \\
\hline Revere SIAP & 510296 & 9.66 & 21.7 & 300 \\
\hline Borgoforte SIAP & 472111 & 14.47 & 0.6 & 300 \\
\hline Boretto & 440404 & 19.23 & 5.7 & 200 \\
\hline Casalmaggiore & 424819 & 21.27 & & 250 \\
\hline Cremona SIAP & 374717 & 29.30 & & 250 \\
\hline Piacenza & 328323 & 42.67 & 69 & 250 \\
\hline Spessa Po & 280692 & 51.32 & 6.3 & 350 \\
\hline Ponte Becca & 269207 & 53.33 & 12.7 & 300 \\
\hline Isola San Antonio & 230559 & 69.33 & 5.9 & 250 \\
\hline Ponte Valenza SIAP & 208377 & 84.40 & 1.1 & 200 \\
\hline Casale Monferrato & 184378 & 104. & 6.0 & 150 \\
\hline Crescentino & 151150 & 146.48 & 35.5 & 100 \\
\hline San Sebastiano & 137555 & 166.28 & 6.2 & 100 \\
\hline Torino Murazzi & 109322 & 210.35 & 6.0 & 100 \\
\hline Carignano & 85767 & 222.90 & 6.2 & 75 \\
\hline
\end{tabular}

The hourly in situ data has some missing values. In general, CryoSat-2 observations were compared to the in situ observation closest in time. A time difference of up to 4 hours was allowed; if no in situ observation existed within these 4 hours the respective CryoSat-2 observation was not evaluated.

The CryoSat-2 data was transferred to the closest in situ stations by applying a constant slope of approximately $0.12 \mathrm{~m} \mathrm{~km}^{-1}$ for the 11 most downstream stations. This slope was estimated from the CryoSat-2 observations, deducting the artificial drop at the dam at Isola Serafini around river kilometer 355. For the upstream stations, where the river has more variable slopes, the slope of the fitted curve within $10 \mathrm{~km}$ around each station was used.

\subsection{Hydrodynamic model}

A 1D hydrodynamic model of the Po River was set up in the DHI MIKE 11 software (DHI, 2015a). The MIKE 11 routing model is based on the dynamic wave Saint-Venant equations for unsteady flow (Havnø et al., 1995), 
and solved using a 6-point implicit finite difference scheme (Abbott and Ionescu, 1967). The model used here is based on the models used by AIPo for their flood forecasting system along the Po River, which were developed by DHI Italy. It uses surveyed cross section geometries from an AIPo survey in 2005 (data available at the AIPo Geoportale at http://geoportale.agenziapo.it/cms/index.php?option=com_aipografd3). The channel setup was simplified slightly, without relevant impacts on the simulated water levels. In the original setup used in the forecasting system, the river discharge was forced by runoff generated by rainfall-runoff models. Using near-real time observed rainfall (and temperature etc.) and forecasts of rainfall, this allows to provide flood forecast a few days ahead. We, however, use the model for validation of CryoSat-2 data and channel roughness calibration. Hence, we directly forced the model by observed discharge.

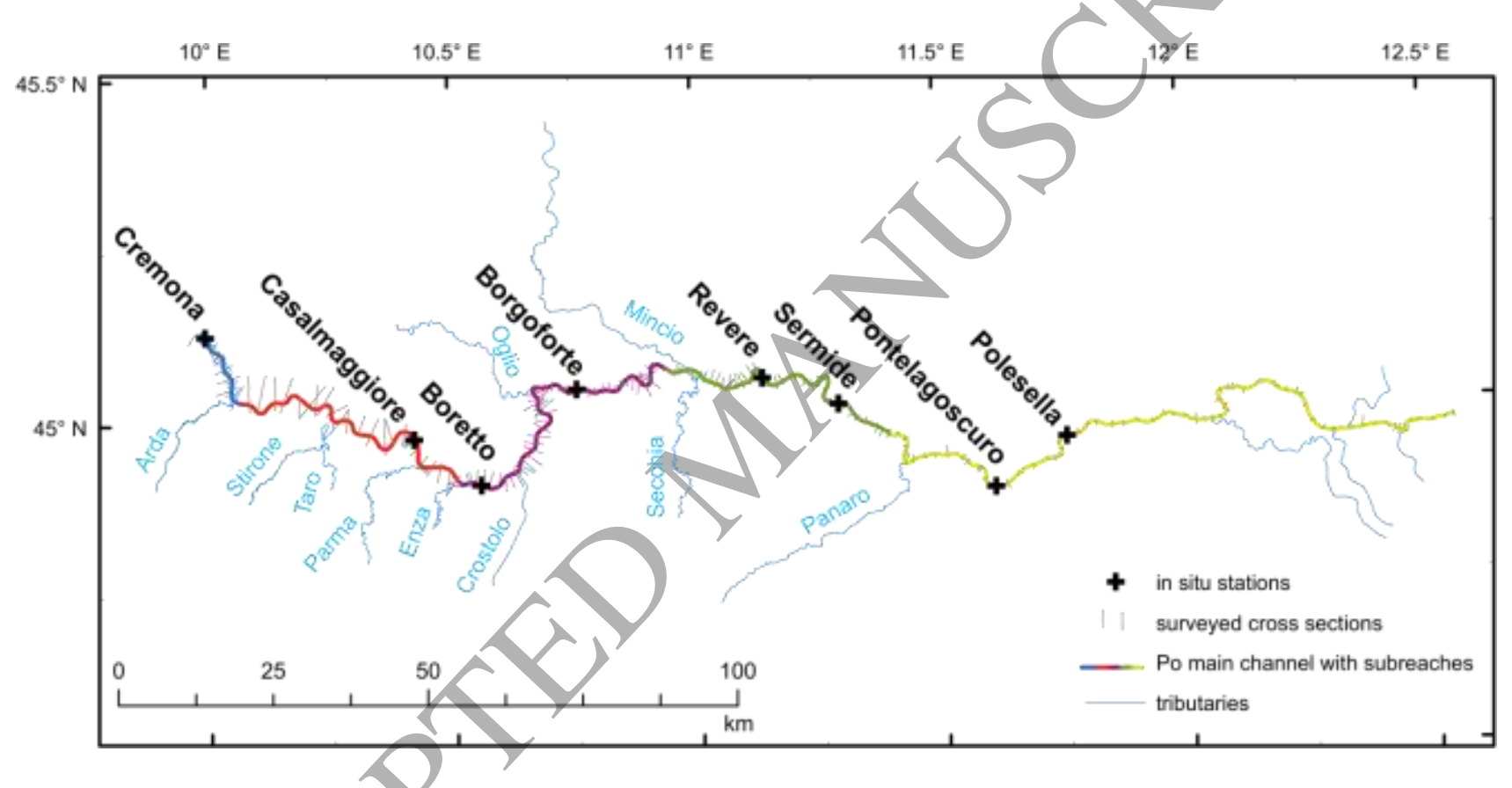

Figure 3: Po River hydrodynamic model overview.

The model was set up from Cremona to the estuary of the Po River in the Adriatic Sea, for the period from 0101-2010 to 01-01-2016. This is a stretch of approximately $281 \mathrm{~km}$, for which 239 surveyed cross sections are available. Cremona (also indicated in Figure 2) was chosen as the upstream boundary as it is the first station downstream of the dam at Isola Serafini. Hence, we did not have to take into account the management of the release from the dam. The model is forced with hourly observed discharge from Cremona station and daily discharge data from the ten tributaries indicated in Figure 3, where Cremona accounts for $77 \%$ of the total inflow volume. The observed discharge data are derived from rating curves and originate from the hydrological yearbooks of AIPo (https://www.arpae.it/sim/?idrologia/annali_idrologici). Figure 3 provides an overview of the hydrodynamic model setup, including the main tributary inflows. 


\subsection{Channel roughness calibration}

Because a dense sample of surveyed cross section is available, and because observed river discharge is used to force the hydrodynamic model, the remaining model uncertainty is essentially due to the unknown channel roughness (disregarding structural uncertainty of the large-scale 1D hydrodynamic model). Hence, model calibration was limited to calibrate the channel roughness to fit simulated and observed water levels. In the chosen model, channel roughness is represented by a Manning's number. Channel roughness naturally is varying along a river. However, it cannot be observed easily. Commonly, it is estimated empirically or, as in our case, it is derived from model calibration.

In a base setup, the modelled stretch of the Po River was divided into five subreaches (see Figure 3). The partitioning was based on Zannoni (2010) and the same approach was adopted for hydraulic model calibration by Domeneghetti et al. (2014). It takes hydromorphological properties of the river into account as well as the distribution of in situ stations. Two setups were considered: first, the simplest case assuming homogenous channel roughness for each subreach. Second, the channel was divided across the profile, where the triple zone approach of MIKE 11 (DHI, 2015b, p. 316) was used to describe channel roughness. Here, the wetted perimeter in each subreach is vertically divided into three zones, each with a distinct roughness. The lowest zone of the channel is assumed to be submerged all year round, the middle zone is an intermediate zone, and the highest zone is the floodplain. The division limits are implemented manually. It is assumed that the roughness of the lowest zone is lowest, whilst the roughness of the highest zone, the floodplain, is highest.

The roughness values were calibrated using a non- linear least-squares solver in Matlab (lsqnonlin) with a Levenberg-Marquardt algorithm. The objective for the calibration runs was to minimize the root mean square error (RMSE) between $n$ observed and simulated water levels

$$
R M S E=\sqrt{\frac{1}{n} \sum_{i=1}^{n}\left(h_{o b s, i}-h_{s i m, i}\right)^{2}}
$$

where $h_{o b s, i}$ are the observed water levels and $h_{s i m, i}$ the respective simulated water levels. For the triple zone approach, a constraint was applied to force the roughness to be increasing from the lowest to the highest zone. Besides this classical division of the river channel into a limited number of subreaches to account for changes of the channel roughness, an approach with channel roughness varying continuously along the river channel was tested. The use of in situ data limits the number of subreaches due to the limited number of stations, whereas CryoSat-2 observations are distributed along the entire river. The high spatial resolution of CryoSat- 2 data was exploited by dividing the river into equal intervals of $10 \mathrm{~km}$ length and fitting the Manning numbers for each 
interval. Due to the larger number of roughness parameters, this approach was only tested with one Manning number for each section, and not for the triple zone approach.

Fitting a model with a large number of parameters, as our case of continuously varying channel roughness, to a limited set of data will often result in overfitting with unrealistic variations of model parameter estimates. Channel roughness, for example, will have some spatial correlation and is not expected to have large variations within $10 \mathrm{~km}$ along a large river like the Po River. This is also a common problem in the inversion of geophysical models, where Occam's inversion is used to obtain a smooth model fit (Constable et al., 1987). In short, Occam's inversion minimizes the model misfit to the data subject to a smoothness constraint that penalizes changes between neighboring model parameters.

In the specific case described in this work, the objective value $O V$ for the yariable channel roughness calibration consisted of the RMSE between simulated and observed water levels - as in equation (1) - and a smoothness objective considering the difference between neighboring roughness values $r_{i}$

$$
O V=\sqrt{\frac{1}{n+m}\left(\sum_{i=1}^{n}\left(h_{o b s, i}-h_{\text {sim }, i}\right)^{2}+f \sum_{i=1}^{m}\left(r_{i+1}-r_{i}\right)^{2}\right)}
$$

where $m$ is the number of channel sections, and $f$ is a weighting between the water level RMSE and the smoothness objective. After convergence of the non-linear least-squares solver, parameter confidence intervals were estimated to evaluate the ability of the data to constrain the model parameters together with the smoothness objective.

In summary, three different model setups were compared in the calibration:

A) the base case: homogenous channel roughness for five subreaches (five parameters to be calibrated);

B) using five subreaches as in A, however with three roughness zones across the cross sections $(5 \times 3=15$ parameters);

C) using homogenous channel roughness for each section as in A, however with $10 \mathrm{~km}$-long sections instead of only five subreaches (29 parameters).

The calibration period was 01-01-2014 to 01-01-2016. Each of the setups A to C were fitted individually to

1) data from eight in situ stations only;

2) data from eight in situ stations and CryoSat-2 observations, weighted equally;

3) CryoSat-2 observations only. 
Data from the in situ stations are available with hourly timestep (with some gaps; see Table 1). From CryoSat-2, there are 375 observations available covering the modelled stretch during the calibration period.

\section{Results and discussion}

\subsection{Evaluation of CryoSat-2 data against in situ data}

The mean error (ME) and RMSE between the $n$ CryoSat-2 altimetry observations and in situ water levels is calculated as follows

$$
\begin{aligned}
& M E=\frac{1}{n} \sum_{i=1}^{n}\left(h_{i n s i t u, i}-h_{C S 2, i}\right) \\
& R M S E=\sqrt{\frac{1}{n} \sum_{i=1}^{n}\left(h_{i n s i t u, i}-h_{C S 2, i}\right)^{2}}
\end{aligned}
$$

Figure 4 shows the results of the slope-corrected, direct evaluation of CryoSat-2 altimetry data over the Po River in the vicinity of the in situ stations, for varying window sizes around each station: the x-axis shows observations within $1 \mathrm{~km}, 2 \mathrm{~km}$, etc., up to $10 \mathrm{~km}$ up- and downstream of each in situ station. Due to the high errors found for the 6 most upstream stations - for a window size of $1 \mathrm{~km}$ the RMSE is already $0.86 \mathrm{~m}$ - those stations were omitted in Figure 4. In order to minimize the error introduced by the constant slope assumption, the observation window had to be limited. As can be seen in Figure 4, the data from some stations (e.g. Sermide, Revere, Borgoforte) shows a steep increase in error when increasing the window size beyond $3 \mathrm{~km}$ to $5 \mathrm{~km}$. Hence, a $3 \mathrm{~km}$ window size is considered a good trade-off between the number of CryoSat-2 observations evaluated and the error introduced by transferring those observations to in situ stations. All further analysis is performed for the $3 \mathrm{~km}$ window, and focuses on the 12 downstream stations. These results are summarized in Table 2 , including the results for the six worse performing upstream in situ stations. 

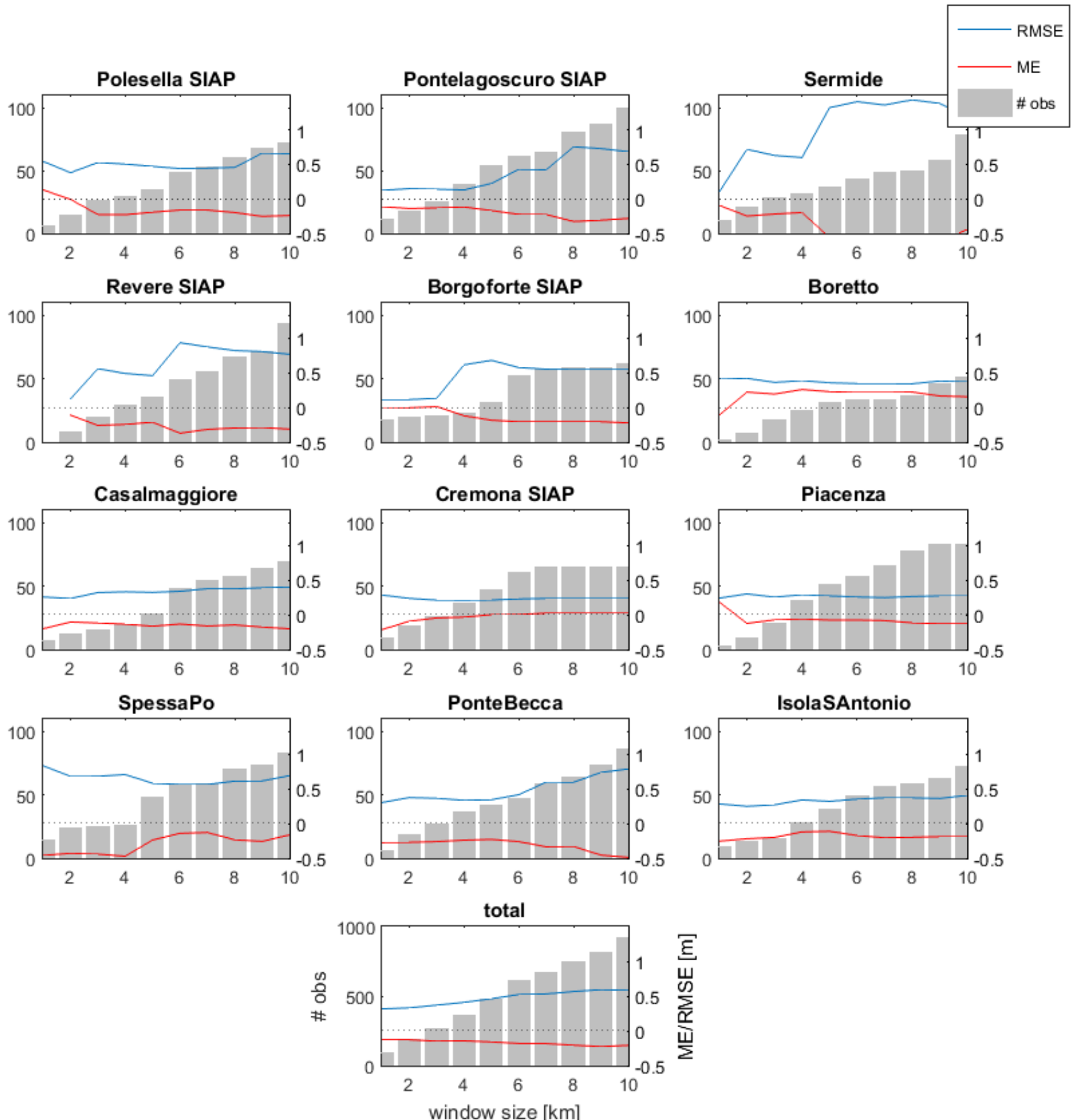

Figure 4: Analysis of CryoSat-2 data against hourly in situ data; in vicinity of 12 downstream stations. X-axis: window size, in km upand downstream around station in which CryoSat-2 observations were analyzed. Left y-axis: number of CryoSat-2 observations. Right y-axis: RMSE (blue) and ME (red) in metres. The last plot presents total number of CryoSat-2 observations and average RMSE and ME values across the 12 downstream stations. 
Table 2: Evaluation of CryoSat-2 observations within a $3 \mathrm{~km}$ window around each in situ station for the three modes LRM, SAR and SARIn. The dashed line separates the 12 downstream stations which are well observed by CryoSat-2 from the upstream stations. Total is sum for the number of observations or the mean RMSE and ME, weighted by the number of observations.

\begin{tabular}{|c|c|c|c|c|c|c|c|c|c|c|c|c|}
\hline & \multicolumn{4}{|c|}{ \# observations } & \multicolumn{4}{|c|}{ RMSE [m] } & \multicolumn{4}{|c|}{$\mathrm{ME}[\mathrm{m}]$} \\
\hline & all & LRM & SAR & $\begin{array}{c}\text { SARI } \\
\mathrm{n}\end{array}$ & all & LRM & SAR & $\begin{array}{c}\text { SARI } \\
\mathrm{n}\end{array}$ & all & LRM & SAR & $\begin{array}{c}\text { SARI } \\
\mathrm{n}\end{array}$ \\
\hline Polesella SIAP & 26 & 0 & 26 & 0 & 0.53 & - & 0.53 & - & -0.23 & & -0.23 & - \\
\hline Pontelagoscuro SIAP & 25 & 0 & 25 & 0 & 0.14 & - & 0.14 & - & -0.13 & & -0.13 & - \\
\hline Sermide & 28 & 0 & 28 & 0 & 0.63 & - & 0.63 & - & -0.22 & & -0.22 & - \\
\hline Revere SIAP & 20 & 0 & 15 & 5 & 0.55 & - & 0.62 & 0.33 & -0.26 & & -0.27 & -0.24 \\
\hline Borgoforte SIAP & 21 & 13 & 4 & 4 & 0.13 & 0.15 & 0.06 & 0.12 & 0.01 & & -0.05 & -0.10 \\
\hline Boretto & 17 & 9 & 5 & 3 & 0.36 & 0.43 & 0.11 & 0.38 & 0.19 & 0.39 & 0.09 & -0.23 \\
\hline Casalmaggiore & 15 & 6 & 3 & 6 & 0.32 & 0.22 & 0.29 & 0.40 & -0.12 & 0.13 & -0.25 & -0.31 \\
\hline Cremona SIAP & 26 & 10 & 8 & 8 & 0.21 & 0.19 & 0.15 & 0.27 & -0.05 & 0.09 & -0.04 & -0.22 \\
\hline Piacenza & 21 & 12 & 6 & 3 & 0.25 & 0.22 & 0.30 & 0.25 & -0.07 & 0.01 & -0.28 & 0.00 \\
\hline Spessa Po & 25 & 15 & 5 & 5 & 0.68 & 0.72 & 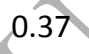 & 0.79 & -0.44 & -0.43 & -0.37 & -0.55 \\
\hline Ponte Becca & 27 & 16 & 7 & 4 & 0.36 & 0.37 & 4 & 0.36 & -0.26 & -0.21 & -0.33 & -0.34 \\
\hline Isola San Antonio & 15 & 10 & 3 & 2 & 0.27 & 0.25 & 0.23 & 0.38 & -0.20 & -0.22 & -0.21 & -0.08 \\
\hline Ponte Valenza SIAP & 10 & 5 & 0 & 5 & 0.70 & 0.50 & - & 0.86 & -0.59 & -0.47 & - & -0.71 \\
\hline Casale Monferrato & 17 & 9 & 1 & 7 & 2.79 & & 2.03 & 2.47 & -0.81 & -1.07 & 2.03 & -0.92 \\
\hline Crescentino & 9 & 2 & 3 & 4 & 1.27 & 0.35 & 1.29 & 1.39 & -0.99 & 0.35 & -1.14 & -1.21 \\
\hline San Sebastiano & 8 & 3 & 1 & 4 & 1.01 & 1.52 & 0.60 & 0.46 & -0.71 & -1.42 & -0.60 & -0.21 \\
\hline Torino Murazzi & 11 & 6 & 1 & 4 & 1.52 & 1.56 & 0.77 & 1.60 & -1.31 & -1.46 & -0.77 & -1.23 \\
\hline Carignano & 23 & 12 & 6 & & 0.67 & 0.74 & 0.59 & 0.60 & 0.20 & 0.31 & -0.13 & 0.32 \\
\hline total, all stations & 344 & 128 & 147 & 69 & 0.60 & 0.66 & 0.44 & 0.77 & -0.25 & -0.21 & -0.21 & -0.42 \\
\hline total, 12 ds. stations & 266 & 91 & & & 0.38 & 0.34 & 0.40 & 0.37 & -0.16 & -0.06 & -0.20 & -0.25 \\
\hline
\end{tabular}

The reduced river width along the six upstream stations leads to a lower number of CryoSat-2 observations, further impeding the analysis of the upstream part. Considering the average across the 12 downstream stations, LRM seems to outperform the other modes slightly. For the stations where both LRM and SAR mode observations exist (Borgoforte to Isola San Antonio), the range of station RMSE values of the SAR mode $(0.06 \mathrm{~m}$ to $0.37 \mathrm{~m})$, however, is smaller than the one of the LRM mode $(0.15 \mathrm{~m}$ to $0.72 \mathrm{~m})$. The mostly negative ME indicate that CryoSat-2 tends to overestimate the observed water levels. This is also visible in Figure 5, which shows a scatterplot of all observations within $3 \mathrm{~km}$ of the 12 downstream stations considered in Table 2 . In Figure 5, all water heights were normalized to the mean of the observed water heights of each station. 


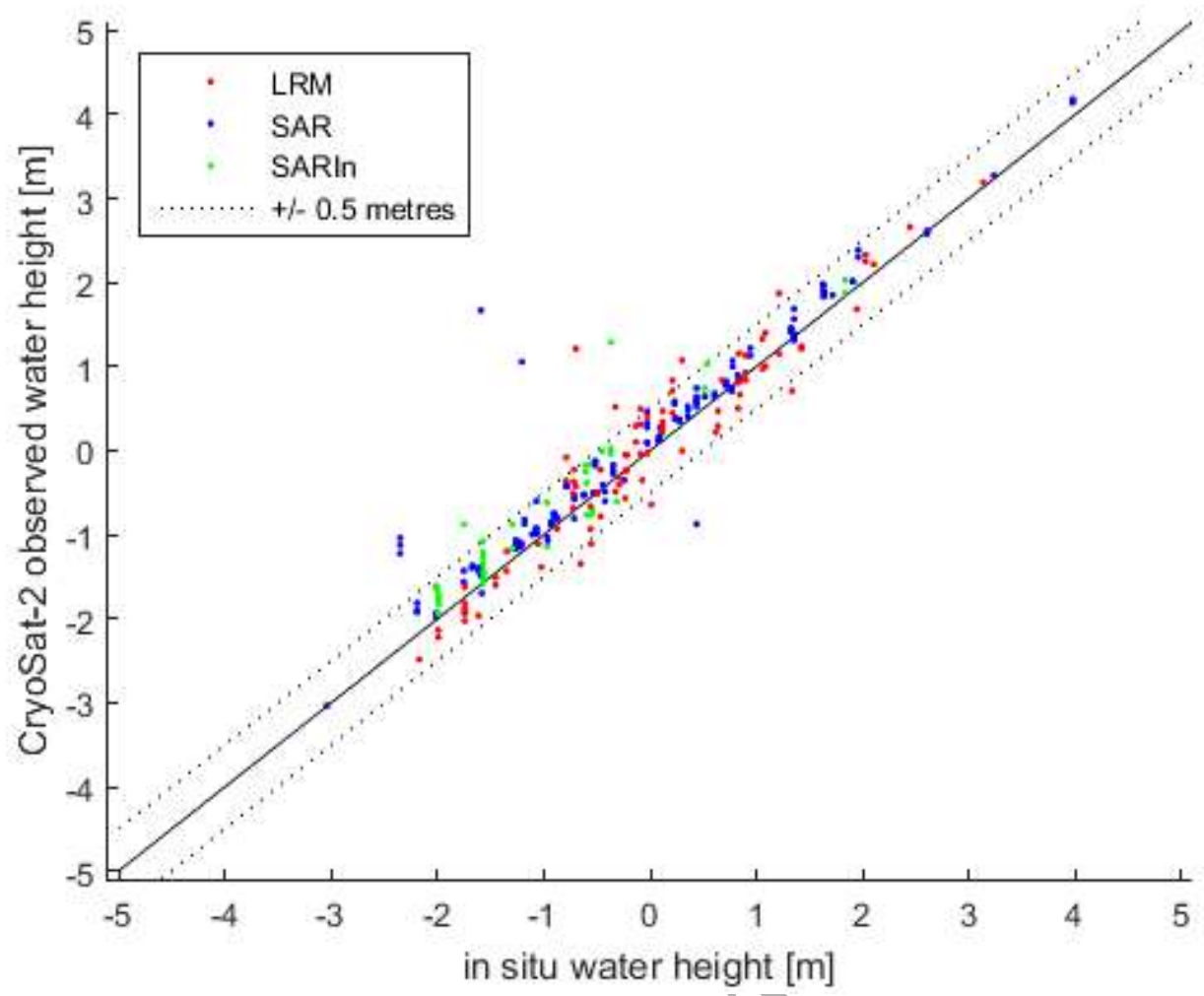

Figure 5: Scatterplot of in situ water heights vs. CryoSat-2 observed water heights for the 12 downstream stations, within 3 km of each station. All values are normalized to mean of observed water levels at each station.

Interestingly, no consistent difference in the performance of the three modes LRM, SAR, and SARIn can be seen. SAR and SARIn mode have a footprint size of approximately $300 \mathrm{~m}$ in along-track direction and $1.65 \mathrm{~km}$ in across-track direction, while in LRM it is a circle with a diameter of theoretically $1.65 \mathrm{~km}$ (European Space Agency and Mullard Space Science Laboratory, 2012). The footprint is even larger on rough surfaces by up to an order of magnitude, which is a general characteristic of radar altimetry (Chelton et al., 2001). Hence, performance differences could be expected because waveforms are less contaminated with land signals in SAR and SARIn modes. At least for the Po River, however, the conventional LRM mode seems to be able to measure the river water level as reliably as the more advanced SAR modes.

The RMSE found in this study of just below $40 \mathrm{~cm}$ is comparable to other studies over rivers performed with virtual station altimetry (Villadsen et al., 2016). Most evaluated rivers, such as the Mekong River or the Amazon River and its tributaries, are, however, wider than the Po River that has an average width of approximately $300 \mathrm{~m}$. When comparing to other studies over the Po River, CryoSat-2 seems to outperform previous satellite altimetry missions: Tarpanelli et al. (2013) found higher observation errors for ERS-2 and Envisat over the Po 
River with RMSE from 0.59 to $0.87 \mathrm{~m}$ when compared to gauged data from Sermide and Pontelagoscuro stations.

Upstream of the station Ponte Becca, CryoSat-2 observation error was found to be larger. This is likely related to the smaller size of the river in this region with a width of only $75 \mathrm{~m}$ to $200 \mathrm{~m}$ (see Table 1). Besides that, the topography surrounding the river also has an impact on the performance of the altimeter. SIRAL, the altimeter on CryoSat-2, adapts the range window, i.e. the window where the altimeter is sensitive to observations, using an on-board tracker (European Space Agency and Mullard Space Science Laboratory, 2012). This is referred to as closed-loop control (Rosmorduc et al., 2011), and commonly leads to increased errors or complete inability to observe the water surface in steep valleys (Biancamaria et al., 2017; Dehecq et al., 2013). Another part of the increased error can also be attributed to the slope correction. The downstream parts of the Po River have more constant slopes, and consequently slope estimation is more reliable. Applying actual river slope would be optimal. Actual river slope is variable across space and time or flow regime, and could for example be retrieved from a hydrodynamic model. We chose, however, to base the evaluation solely on observation data.

\subsection{Added value of CryoSat-2 for model calibration}

The CryoSat-2 observations were evaluated for calibrating the bed roughness of the MIKE 11 hydrodynamic model of the Po River. Table 3 provides a summary of the different calibration runs. The RMSE values calculated from equation (1) for the calibrated models are presented in the table. The last column presents the confidence interval (CI) of the fitted Manning's $M$ number, which can be estimated from the used non-linear least squares algorithm. It gives an idea of how well the chosen calibration data can define the channel roughness parameters - the smaller the confidence interval, the more well-defined the optimal channel roughness. Setup C was performed with different smoothness weights (referred to as $f$ in equation (2)). Two of them are reported in Table 3. 
Table 3: Po River hydrodynamic model calibration results.

\begin{tabular}{|c|c|c|c|c|c|}
\hline & & $\begin{array}{c}\text { calibration } \\
\text { against }\end{array}$ & $\begin{array}{l}\text { RMSE in situ } \\
{[\mathrm{m}]}\end{array}$ & $\begin{array}{l}\text { RMSE CS-2 } \\
{[\mathrm{m}]}\end{array}$ & $\begin{array}{c}\text { avg. width of } \\
\text { Manning's } M 95 \% \mathrm{Cl} \\
{\left[\mathrm{m}^{1 / 3} \mathrm{~s}^{-1}\right]}\end{array}$ \\
\hline \multirow{3}{*}{ setup $A$} & & 1) in situ & 0.289 & 0.643 & 0.2 \\
\hline & & 2) in situ and CS-2 & 0.291 & 0.639 & 0.5 \\
\hline & & 3) $\mathrm{CS}-2$ & 0.310 & 0.634 & 4.1 \\
\hline \multirow{3}{*}{ setup B } & & 1) in situ & 0.229 & 0.639 & 0.7 \\
\hline & & 2) in situ and CS-2 & 0.238 & 0.628 & 1.7 \\
\hline & & 3) $\mathrm{CS}-2$ & 0.450 & 0.622 & $54.7(14$ \\
\hline \multirow{6}{*}{ setup C } & medium & 1) in situ & 0.260 & 0.610 & 7.8 \\
\hline & smoothness & 2) in situ and CS-2 & 0.262 & 0.573 & 1.5 \\
\hline & weight & 3) $\mathrm{CS}-2$ & 0.311 & 0.563 & 13.8 \\
\hline & high & 1) in situ & 0.269 & 0.616 & 21.1 \\
\hline & smoothness & 2) in situ and CS-2 & 0.267 & 0.595 & 0.8 \\
\hline & weight & 3) $\mathrm{CS}-2$ & 0.282 & 0.583 & 7.4 \\
\hline
\end{tabular}

In general, a finer representation of the channel roughness (setups B and C) allows a better model fit than the coarse channel roughness representation in setup A. Nonetheless, the finer channel roughness representation comes at the expense of a higher uncertainty of the fitted parameters. This is for example noticeable in calibration B3 which uses CryoSat-2 data, and results in a low confidence in the fitted Manning's $M$ value. Because only 13 of the 375 CryoSat- 2 observations fall into the most upstream of the five subreaches, the parameters are particularly badly defined here. The value in brackets (14.6) refers to the average when the most upstream subreach is omitted.

Not surprisingly, it can be seen for each setup that calibrating against in situ data will result in the best fit to in situ data and worst fit to CryoSat-2, while calibrating against CryoSat-2 data will result in the best fit CryoSat-2 and worst fit to in situ data. Still, except for setup B3 (due to the above mentioned inability of the data to constrain the parameters), the differences in the data fits between calibrations against in situ or CryoSat- 2 data are small. For the base setup A, for example, the in situ fit only deteriorates by approximately $2 \mathrm{~cm}$ or $7 \%$ when calibrating against CryoSat-2 data instead of in situ data. This is remarkable considering observation uncertainty of CryoSat -2 of around $38 \mathrm{~cm}$, and indicates a general good agreement between in situ and CryoSat-2 observations. The CryoSat-2 data alone is sufficient to calibrate the model channel roughness. In contrast, using in situ data only cannot reasonably constrain variable channel roughness (C1), as can be seen from the large parameter confidence intervals. This might be surprising, as (i) CryoSat-2 has a much lower accuracy than the in situ data, and (ii) CryoSat-2 samples the modelled river stretch only 375 times during the calibration period, 
while there exist approximately 130,000 individual hourly observations from the in situ stations. Possibly the better spatial resolution of the sampling by CryoSat- 2 compensates for its lower temporal resolution and accuracy. The results indicate that the variable channel roughness (setup C) is best calibrated using a combination of in situ data with high temporal resolution and CryoSat-2 data with high spatial resolution. The smoothness weight provides a trade-off between model fit and parameter confidence. Different values were tested during this work; the two most suitable are presented in Table 3. A smaller smoothness weight is able to provide an even better model fit, however, at the cost of poorly defined parameters. A higher smoothness weight will constrain variability in bed roughness along the channel too much. A study by Domeneghettiet al. (2014) calibrating channel roughness in a HEC-RS hydrodynamic model of the Po River using ERS-2 and Envisat data found Manning's $M$ numbers ranging from 23 to $40 \mathrm{~m}^{1 / 3} \mathrm{~s}^{-1}$. This compares well to the values obtained, for example in our setup B3, where the Manning's $M$ values range from 26 to $35 \mathrm{~m}^{1 / 3} \mathrm{~s}^{-1}$.

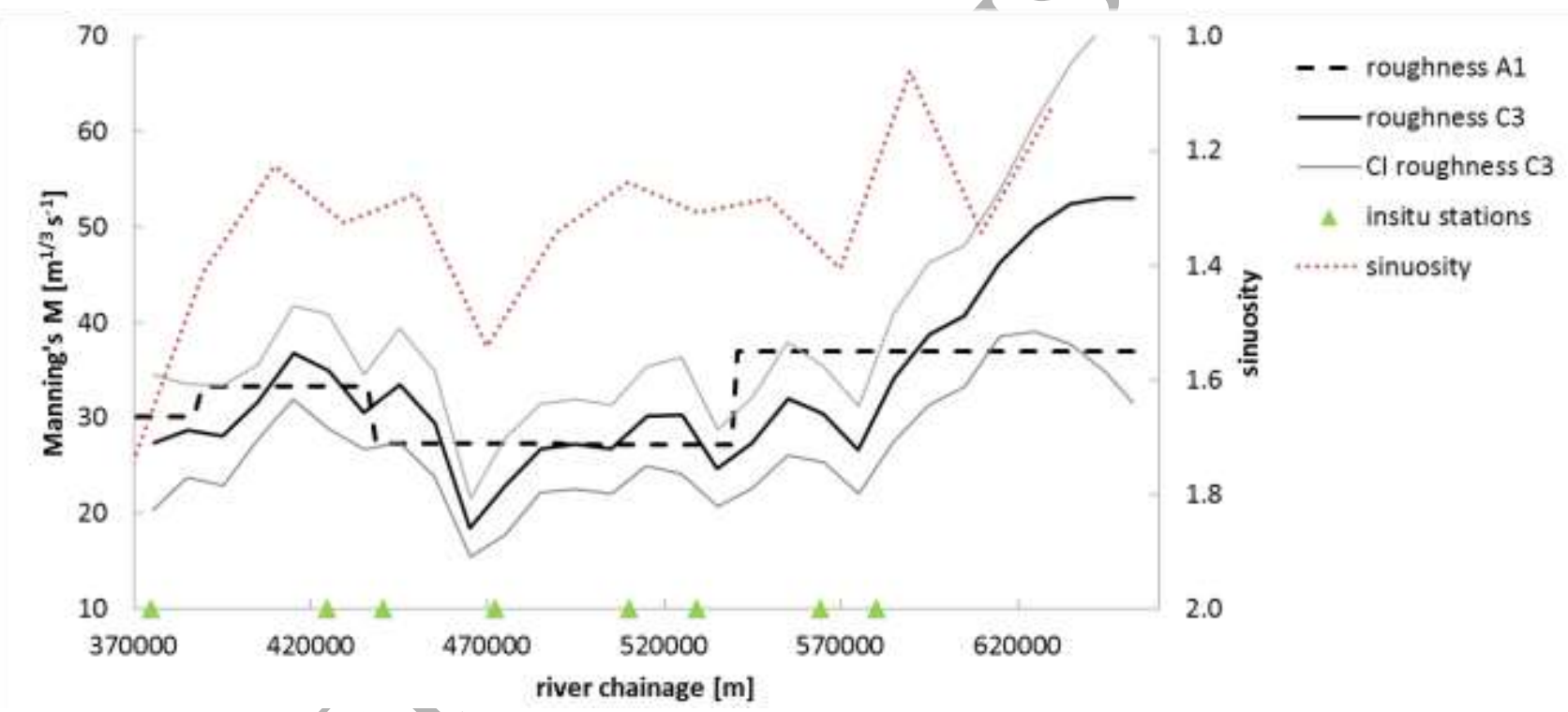

Figure 6: Comparing results from the roughness calibration with five subreaches to variable roughness calibration. River sinuosity is displayed for comparison with the variable roughness. Refer to the text for details.

Figure 6 displays the calibrated channel roughness values for an example of the setup with five subreaches (A1, i.e. calibrated against in situ data only) and an example with variable roughness and medium smoothness weight (C3, i.e. calibrated against CryoSat-2 data only). C3 is displayed together with the $95 \%$ confidence intervals of the calibrated roughness. The variable roughness of $\mathrm{C} 3$ follows somewhat the roughness obtained in $\mathrm{A} 1$, which is fixed along each subreach. This confirms the validity of the variable channel roughness values and the added value provided by CryoSat-2 water level observations for model calibration. 
Channel roughness in a 1D hydrodynamic model is a lumped parameter affected by a number of properties of the respective river channel. The actual surface roughness is just one of those properties (Chow, 1959, chapter 5-7). Also the curvature of the river affects the channel roughness, especially for hydrodynamic models which do not take into account effects related to curvature. The more curves a channel has, the higher one expects the effective channel roughness to be, because of additional boundary shear introduced by channel curvature. This is for example expressed in various empirical formulas to estimate the Manning's number (James, 1994). Such effects can also be shown in laboratory experiments (Khatua et al., 2011). As a measure of river curvature, the sinuosity $S$ is defined as

$$
S=\frac{\text { channel length }}{\text { direct distance }}
$$

where the channel length is the distance following the river channel between two points on the river. Divided by the direct distance between those two points, this means that a sinuosity $S$ of 1 is the minimum and indicates a straight channel, and increasing values represent a more and more curved river.

In our case, the sinuosity was calculated for $20 \mathrm{~km}$ sections along the Po River (see Figure 6). The naked eye can see that the calibrated variable channel roughness is somewhat correlated to the sinuosity. When calculated, the coefficient of correlation $R$ between sinuosity and variable Manning's $M$ number is 0.48 . This further validates the calibrated variable channel roughness.

The presented calibration efforts show the value of observations of dense water level profiles along rivers. Their value in the estimation of hydraulic parameters also has been acknowledged in previous research (Garambois et al., 2016; O’Loughlin et al., 2013; Schumann et al., 2010; Trigg et al., 2009). It is hard to observe water level profiles from current altimetry missions. This is where the application of CryoSat-2 altimetry, or the combination of altimetry data from multiple short-repeat missions (Boergens et al., 2017; Tourian et al., 2016), can bridge a gap to the upcoming NASA Surface Water and Ocean Topography (SWOT) mission. It is scheduled to be launched in 2021, and will be able to deliver such information, as it basically delivers images of surface elevation (Biancamaria et al., 2016). All past and current satellite altimeters deliver such information at discrete points only. To date, there already exists a wide array of literature trying to evaluate the potential of SWOT observed water levels and water level profiles. For example the direct estimation of river discharge should be made possíble; Biancamaria et al. (2016) provide an overview over possible applications. 


\section{Summary and conclusions}

One key challenge in processing CryoSat-2 altimetry data for rivers and using it in hydrological applications is its long repeat orbit resulting in a drifting ground track, and a distributed spatio-temporal sampling pattern. All previously used satellite radar altimeter missions have been on a short repeat orbits, resulting in so-called virtual station time series of observed water levels at specified locations. This challenge may be one of the reasons why CryoSat-2 still is only used sparsely by hydrologists (Jiang et al., 2017). This work presents a method for evaluating CryoSat-2 data. Furthermore, we highlight its usefulness for hydrodynamic model calibration, where the unique spatio-temporal sampling pattern creates added value over using data at discrete locations from gauging stations or virtual station altimetry.

Across 12 in situ stations along the Po River, Italy, the average RMSE of CryoSat-2 compared with hourly water level observations was $0.38 \mathrm{~m}$. Another six in situ stations located more upstream showed significantly worse performance, likely due to a narrower river channel, steeper river valley, and issues with slope correction. The slope correction also has its limitations for the 12 downstream stations as is expressed in the error increasing with increasing window size. The performance for the 12 downstream stations is in the range of previous satellite altimetry validation studies over rivers (Villadsen et al., 2016). Interestingly, no relevant difference in the performance of the LRM, SAR, and SARIn operational modes of CryoSat-2 could be shown. This indicates that CryoSat-2 altimetry can deliver useful water level observations over a large number of rivers worldwide, as even the conventional LRM mode of the altimeter deliyers good results. Also, the Po River is a fairly narrow target with a width of approximately $300 \mathrm{~m}$, which indicates transferability to many other rivers of the same or larger size (for global analysis of river widths refer to Pavelsky et al., 2014 and Yamazaki et al., 2014).

CryoSat-2 water level observations are distributed continuously along a river, instead of having a significant spacing as virtual station altimetry. Even over densely monitored rivers such as the Po River where there exists a dense network of in situ stations (on average one station every $~ 30 \mathrm{~km}$ along the modelled river stretch), CryoSat-2 data still can deliver additional information, despite its lower accuracy than most in situ observations. This was shown in combination with a 1D hydrodynamic model of the Po River. The model channel roughness was calibrated against in situ and CryoSat-2 observations of water levels. The possibility of resolving channel roughness variations along a river in a conventional setup using in situ stations is limited by the spacing of the in situ stations. CryoSat-2 data offers a globally available option to cover these gaps, especially if the use of more complex tools for roughness estimation (such as the Conveyance and Afflux Estimation System (CES/AES), HR Wallingford Ltd, 2004) is not possible. This potentially results in a better fit of simulated water levels along the entire river instead of having best fit at the exact locations of the in situ stations only. Also, the calibrated 
variable channel roughness obtained from calibrating the model against CryoSat-2 data could be shown to be mildly correlated with the sinuosity of the river.

Generally speaking, this paper can be seen as a motivation to use satellite altimetry data beyond the established concept of virtual station data: data from CryoSat-2, or combined multi-mission data, can deliver more than just water level time series at discrete points, but also water level profiles. These data provide added value over conventional data for the hydraulic characterization of rivers and, as shown in this work, for the calibration of hydrodynamic river models.

\section{Acknowledgements}

We would like to thank the Interregional Agency for the Po River (Agenzia Interregionale per il Fiume Po, AIPo) and DHI Italy for providing the MIKE 11 model of the Po River used in our study. Thanks to Federica Pellegrini for providing us technical information about the analyzed data for the Po River and Marco Baldo for the processing related to the geoid. Furthermore, the analyzed CryoSat-2 level 2 data was kindly provided by the National Space Institute, Technical University of Denmark. Funding from the LOTUS - Preparing Sentinel-3 SAR Altimetry Processing for Ocean and Land project (EU FP7, grant no. 313238) and the CryoSat-2 Success over Inland Water and Land (CRUCIAL) project (ITT ESRIN/AO/1-6827/11/I-NB) is gratefully acknowledged.

\section{References}

Abbott, M.B., Ionescu, F., 1967. On The Numerical Computation Of Nearly Horizontal Flows. J. Hydraul. Res. 5, 97-117. doi:10.1080/00221686709500195

Alsdorf, D.E., Rodríguez, E., Lettenmaier, D.P., 2007. Measuring Surface Water From Space. Rev. Geophys. 45. doi:10.1029/2006RG000197

Barzaghi, R., Borghi, A., Carrion, D., Sona, G., 2007. Refining the estimate of the Italian quasi-geoid. Boll. di Geod. e Sci. Affin. 66.

Bercher, N., Calmant, S., Picot, N., Seyler, F., Fleury, S., 2013. Evaluation of Cryosat-2 Measurements for the Monitoring of Large River Water Levels, in: Ouwehand, L. (Ed.), Proceedings of 20 Years of Progress in Radar Altimetry. European Space Agency, Venice, Italy.

Berry, P.A.M., Benveniste, J., 2010. Measurement of Inland Surface Water from Multi-mission Satellite Radar Altimetry: Sustained Global Monitoring for Climate Change, in: Mertikas, S.P. (Ed.), Gravity, Geoid and Earth Observation, International Association of Geodesy Symposia. Springer Berlin Heidelberg, pp. 221229. doi:10.1007/978-3-642-10634-7

Biancamaria, S., Frappart, F., Leleu, A.-S., Marieu, V., Blumstein, D., Desjonquères, J.-D., Boy, F., Sottolichio, A., Valle-Levinson, A., 2017. Satellite radar altimetry water elevations performance over a $200 \mathrm{~m}$ wide river: Evaluation over the Garonne River. Adv. Sp. Res. 59, 128-146. doi:10.1016/j.asr.2016.10.008 
Biancamaria, S., Lettenmaier, D.P., Pavelsky, T.M., 2016. The SWOT Mission and Its Capabilities for Land Hydrology. Surv. Geophys. 37, 307-337. doi:10.1007/s10712-015-9346-y

Birkinshaw, S.J., Moore, P., Kilsby, C.G., O’Donnell, G.M., Hardy, A.J., Berry, P.A.M., 2014. Daily discharge estimation at ungauged river sites using remote sensing. Hydrol. Process. 28, 1043-1054. doi:10.1002/hyp.9647

Boergens, E., Buhl, S., Dettmering, D., Klüppelberg, C., Seitz, F., 2017. Combination of multi-mission altimetry data along the Mekong River with spatio-temporal kriging. J. Geod. 91, 519-534. doi:10.1007/s00190-0160980-z

Calmant, S., Crétaux, J.-F., Rémy, F., 2016. Principles of Radar Satellite Altimetry for Application on Inland Waters, in: Baghdadi, N., Zribi, M. (Eds.), Microwave Remote Sensing of Land Surface. Elsevier, pp. 175218. doi:10.1016/B978-1-78548-159-8.50004-9

Calmant, S., Seyler, F., 2006. Continental surface waters from satellite altimetry. Comptes Rendus Geosci. 338, 1113-1122. doi:10.1016/j.crte.2006.05.012

Calmant, S., Seyler, F., Cretaux, J.F., 2009. Monitoring Continental Surface Waters by Satellite Altimetry. Surv. Geophys. 29, 247-269. doi:10.1007/s10712-008-9051-1

Chelton, D.B., Ries, J.C., Haines, B.J., Fu, L.-L., Callahan, P.S., 2001. Satellite Altimetry, in: Fu, L., Cazenave, A. (Eds.), Satellite Altimetry and Earth Sciences: A Handbook of Techniques and Applications, International Geophysics. Academic Press, San Diego, pp. 1-131.

Chow, V.T., 1959. Open Channel Hydraulics, McGraw-Hill Book Company. McGraw-Hill, New York. doi:ISBN 07-010776-9

Constable, S.C., Parker, R.L., Constable, C.G., 1987. Occam's inversion: A practical algorithm for generating smooth models from electromagnetic sounding data. Geophysics 52, 289-300. doi:10.1190/1.1442303

Dehecq, A., Gourmelen, N., Shepherd, A., Cullen, R., Trouvé, E., 2013. Evaluation of CryoSat-2 for height retrieval over the Himalayan range, in: Ouwehand, L. (Ed.), CryoSat-2 Third User Workshop. European Space Agency, Dresden, Germany.

DHI, 2015a. MIKE 11 - A Modelling System for Rivers and Channels - Reference Manual. Hørsholm, Denmark.

DHI, 2015b. MIKE 11 - A Modelling System for Rivers and Channels - User Guide. Hørsholm, Denmark.

Domeneghetti, A., Tarpanelli, A., Brocca, L., Barbetta, S., Moramarco, T., Castellarin, A., Brath, A., 2014. The use of remote sensing-derived water surface data for hydraulic model calibration. Remote Sens. Environ. 149, 130-141.doi:10.1016/j.rse.2014.04.007

European Space Agency, Mullard Space Science Laboratory, 2012. CryoSat Product Handbook.

Frappart, F., Calmant, S., Cauhopé, M., Seyler, F., Cazenave, A., 2006. Preliminary results of ENVISAT RA-2derived water levels validation over the Amazon basin. Remote Sens. Environ. 100, 252-264. doi:10.1016/j.rse.2005.10.027

Garambois, P.-A., Calmant, S., Roux, H., Paris, A., Monnier, J., Finaud-Guyot, P., Montazem, A., Santos da Silva, J., 2016. Hydraulic visibility: using satellite altimetry to parameterize a hydraulic model of an ungauged reach of a braided river. Hydrol. Process. doi:10.1002/hyp.11033 
Göttl, F., Dettmering, D., Müller, F., Schwatke, C., 2016. Lake Level Estimation Based on CryoSat-2 SAR Altimetry and Multi-Looked Waveform Classification. Remote Sens. 8, 885. doi:10.3390/rs8110885

Havnø, K., Madsen, M.N., Dørge, J., 1995. MIKE 11 - A Generalized River Modelling Package, in: Singh, V.P. (Ed.), Computer Models of Watershed Hydrology. Water Resource Publications, Highlands Ranch, CO, pp. 733-782.

HR Wallingford Ltd, 2004. Conveyance Manual, Reducing uncertainity in river flood conveyance, phase 2. Project Record W5A-057/PR/1.

James, C.S., 1994. Evaluation of Methods for Predicting Bend Loss in Meandering Channels. J. Hydraul. Eng. 120, 245-253. doi:10.1061/(ASCE)0733-9429(1994)120:2(245)

Jarihani, A.A., Callow, J.N., Johansen, K., Gouweleeuw, B., 2013. Evaluation of multiple satellite altimetry data for studying inland water bodies and river floods. J. Hydrol. 505, 78-90. doi:10.1016/j.jhydrol.2013.09.010

Jiang, L., Schneider, R., Andersen, O., Bauer-Gottwein, P., 2017. CryoSat-2 Altimetry Applications over Rivers and Lakes. Water 9, 211. doi:10.3390/w9030211

Khatua, K.K., Patra, K.C., Nayak, P., 2011. Meandering effect for evaluation of roughness coefficients in open channel flow. WIT Trans. Ecol. Environ. 146, 213-226. doi:10.2495/RM110191

Maillard, P., Bercher, N., Calmant, S., 2015. New processing approaches on the retrieval of water levels in Envisat and SARAL radar altimetry over rivers: A case study of the São Francisco River, Brazil. Remote Sens. Environ. 156, 226-241. doi:10.1016/j.rse.2014.09.027

Michailovsky, C.I., McEnnis, S., Berry, P.A.M., Smith, R., Bauer-Gottwein, P., 2012. River monitoring from satellite radar altimetry in the Zambezi River Basin. Hydrol. Earth Syst. Sci. 16, 2181-2192. doi:10.5194/hess-16-2181-2012

Montanari, A., 2012. Hydrology of the Po River: looking for changing patterns in river discharge. Hydrol. Earth Syst. Sci. 16, 3739-3747. doi:10.5194/hess-16-3739-2012

Neal, J., Schumann, G., Bates, P., 2012. A subgrid channel model for simulating river hydraulics and floodplain inundation over large and data sparse areas. Water Resour. Res. 48, W11506. doi:10.1029/2012WR012514

Nielsen, K., Stenseng, L., Andersen, O.B., Villadsen, H., Knudsen, P., 2015. Validation of CryoSat-2 SAR mode based lake levels. Remote Sens. Environ. 171, 162-170. doi:10.1016/j.rse.2015.10.023

O’Loughlin, F., Trigg, M.A., Schumann, G.J.P., Bates, P.D., 2013. Hydraulic characterization of the middle reach of the Congo River. Water Resour. Res. 49, 5059-5070. doi:10.1002/wrcr.20398

O’Loughlin, F.E., Neal, J., Yamazaki, D., Bates, P.D., 2016. ICESat-derived inland water surface spot heights. Water Resour. Res. 52, 3276-3284. doi:10.1002/2015WR018237

Pavelsky, T.M., Durand, M.T., Andreadis, K.M., Beighley, R.E., Paiva, R.C.D., Allen, G.H., Miller, Z.F., 2014. Assessing the potential global extent of SWOT river discharge observations. J. Hydrol. 519, 1516-1525. doi:10.1016/j.jhydrol.2014.08.044

Rosmorduc, V., Benveniste, J., Bronner, E., Dinardo, S., Lauret, O., Maheu, C., Milagro, M., Picot, N., 2011. Radar Altimetry Tutorial. 
Santos da Silva, J., Calmant, S., Seyler, F., Rotunno Filho, O.C., Cochonneau, G., Mansur, W.J., 2010. Water levels in the Amazon basin derived from the ERS 2 and ENVISAT radar altimetry missions. Remote Sens. Environ. 114, 2160-2181. doi:10.1016/j.rse.2010.04.020

Schneider, R., Godiksen, P.N., Villadsen, H., Madsen, H., Bauer-Gottwein, P., 2017. Application of CryoSat-2 altimetry data for river analysis and modelling. Hydrol. Earth Syst. Sci. 21, 751-764. doi:10.5194/hess-21$751-2017$

Schumann, G., Di Baldassarre, G., Alsdorf, D., Bates, P.D., 2010. Near real-time flood wave approximation on large rivers from space: Application to the River Po, Italy. Water Resour. Res. 46, 1-8, doi:10.1029/2008WR007672

Schutz, B.E., Zwally, H.J., Shuman, C.A., Hancock, D., DiMarzio, J.P., 2005. Overview of the ICESat Mission. Geophys. Res. Lett. 32, L21S01. doi:10.1029/2005GL024009

Schwatke, C., Dettmering, D., Bosch, W., Seitz, F., 2015. DAHITI - an innovative approach for estimating water level time series over inland waters using multi-mission satellite altimetry. Hydrol. Earth Syst. Sci. 19, 4345-4364. doi:10.5194/hess-19-4345-2015

Tarpanelli, A., Barbetta, S., Brocca, L., Moramarco, T., 2013. River discharge estimation by using altimetry data and simplified flood routing modeling. Remote Sens. 5, 4145-4162. doi:10.3390/rs5094145

Tourian, M.J., Tarpanelli, A., Elmi, O., Qin, T., Brocca, L., Moramarco, T., Sneeuw, N., 2016. Spatiotemporal densification of river water level time series by multimission satellite altimetry. Water Resour. Res. 52, 1140-1159. doi:10.1002/2015WR017654

Trigg, M.A., Wilson, M.D., Bates, P.D., Horritt, M.S., Alsdorf, D.E., Forsberg, B.R., Vega, M.C., 2009. Amazon flood wave hydraulics. J. Hydrol. 374, 92-105. doi:10.1016/j.jhydrol.2009.06.004

Villadsen, H., Deng, X., Andersen, O.B., Stenseng, L., Nielsen, K., Knudsen, P., 2016. Improved inland water levels from SAR altimetry using novel empirical and physical retrackers. J. Hydrol. 537, 234-247. doi:10.1016/j.jhydrol.2016.03.051

Villadsen, H., Andersen, O.B., Stenseng, L., Nielsen, K., Knudsen, P., 2015. CryoSat-2 altimetry for river level monitoring - Evaluation in the Ganges-Brahmaputra basin. Remote Sens. Environ. 168, 80-89. doi:10.1016/j.rse.2015.05.025

Wingham, D.J., Francis, C.R., Baker, S., Bouzinac, C., Brockley, D., Cullen, R., de Chateau-Thierry, P., Laxon, S.W., Mallow, U., Mavrocordatos, C., Phalippou, L., Ratier, G., Rey, L., Rostan, F., Viau, P., Wallis, D.W., 2006. CryoSat: A mission to determine the fluctuations in Earth's land and marine ice fields. Adv. Sp. Res 37, 841-871. doi:10.1016/j.asr.2005.07.027

World Water Assessment Programme, 2009. The United Nations World Water Development Report 3: Water in a Changing World, The United Nations World Water Development Report 3. UNESCO and Earthscan, Paris, London.

Yamazaki, D., O’Loughlin, F., Trigg, M.A., Miller, Z.F., Pavelsky, T.M., Bates, P.D., 2014. Development of the Global Width Database for Large Rivers. Water Resour. Res. 50, 3467-3480. doi:10.1002/2013WR014664

Zannoni, E., 2010. Ipotesi di potenziamento della capacità di laminazione del tratto medio-inferiore del Fiume Po attraverso una corretta gestione del sistema di arginature golenali. Università di Bologna. 